\title{
VARIATIONS IN EXPERIENCE AND MEANING: LEADERSHIP INVOLVMENT AND IDENTITIES WITH SPECIAL EDUCATION AND DISABILITIES
}

\author{
Roderick J. Jones \\ Assistant Professor, University of Wisconsin—Eau Claire, USA, jonesrod@uwec.edu
}

\begin{abstract}
This study focused on various ways retired school principals conceived leadership identity and accounted for involvement in special education with students identified or identifying as disabled. Participants' narratives regarding what it meant to be involved with special education and/or disability and relationships between conceptions of involvement and identities served as primary data. Conceptions included, but were not limited to, perceived ways participants viewed their attentiveness and commitment to special education. In this study, identity was understood as a professional identity in relationship to one's social identities and in response to others' social identities. Employing a phenomenographic approach, findings were grouped into pools of meanings, labeled as categories of description, and presented in an outcome space. Findings evinced participants accounted for involvement with special education and/or disability through professional responses, risk-taking, and working toward social transforming their schools. They experienced involvement as active presence, critical reflection, advocacy, and resistance. Findings suggested participants' involvement in special education was influenced by personal experiences with disability and relationships with individuals with disabilities. Participants experienced identity through compassion, learning, spirituality, and dis/abled-ness. Discussion of how leadership preparation programs can recruit and prepare school leaders in special education is provided.
\end{abstract}

Keywords: Principals, Special Education, Disability, Leadership, Involvement, Identity

\section{INTRODUCTION}

School principals are increasingly viewed as instructional leaders responsive to and accountable for meeting the social, emotional, and behavioral needs of every student, including students with disabilities (Bays \& Crockett, 2007; Frick, Faircloth, \& Little, 2013; Frost \& Kersten, 2011). Yet scholarly attention underscoring the significance of leadership with regard to special education is disparate, often foregrounded on principals' ability to lead in response to federal accountability mandates (Bakken, O'Brian, \& Shelden, 2006; Provost, Boscardin, \& Wells, 2010). Furthermore, preparing knowledgeable and confident principals to lead students with disabilities remains a challenge. Despite demands for public schools to operate under more inclusive paradigms (Black \& Simon, 2014; Frattura \& Capper, 2006), leadership preparation is informed by separate general and special education policy and instructional delivery frameworks (Burrello, Sailor, \& KleinhammerTramill, 2013). Increased attention to understanding how leadership is conceived and practiced among various student populations can prompt those in leadership roles to (re)interpret their identity vis- à-vis conceptions of their intergroup leadership practices (Crow, Day, \& Møller, 2017; Rhodes \& Greenway, 2010). 


\subsection{Background and Rationale of Study}

Policy endeavors in the United States safeguard students with disabilities' educative rights (Bineham, Shelby, Pazey, \& Yates, 2014; Fuchs, Fuchs, \& Stecker, 2010; Palladino, 2013; Richter, Lewis, \& Hagar, 2012; Sansosti, Noltemeyer, \& Goss, 2010; Skiba, Simmons, Ritter, Gibb, Rausch, Cuadrado, \& Chung, 2008; Van Acker, Boreson, Gable, Potterton, 2005; Wiener \& Soodak, 2008). However, special education leadership is at an impasse, burrowed in contemporary efforts to address principal shortages, continual shifts in general and special education standards and licensure requirements, and how best to prepare principals to deal with complex policy changes and knowledge needed to administer special education (Lashley \& Boscardin, 2003). Additionally, the extent to which studies have offered insights into leadership and involvement in special education and with students with disabilities attend primarily to correlational relationships between principals' (in)formal preparation and on-the-job experiences derived from surveys (e.g., Christensen, Robertson, Williamson, \& Hunter, 2013; Lasky \& Karge, 2006; Petzko, 2008). Nor does literature illuminate principals' understanding of how identity influences their practice as leaders in special education.

\subsection{Purpose of Study}

This study sought to understand involvement of former principals in special education by unpacking variation in how former principals accounted for their involvement with students identified with disabilities and how they conceived their leadership identity. The following question guided the study: How do former principals account for their involvement with special education and/or disability? The subquestions were:

1. What are principals' accounts of being, becoming, and remaining involved with special education and/or disability?

2. In what ways do principals attend to special education and/or disability?

3. How do principals conceive of their leadership identity given their accounts of involvement with special education and/or disability?

The phenomenon under inquiry was various conceptions or meanings participants' held about what it meant to be involved with special education and/or disability and relationships between conceptions of involvement and identities. Conceptions of involvement included perceived ways participants found personal relevance to engage through attentiveness and commitment (i.e., actions connected to emotional attachment and potentially influenced by their sense of competence and confidence in their leadership) in direct, hands-on leadership in special education and with students with disabilities. Additionally, leadership was understood as a professional identity role that changed in relationship to one's social identities and in response to others' social identities in context and over time.

\section{CONCEPTUAL FRAMEWORK}

The following framework facilitated investigation into former principals' conceptions of involvement in special education, particularly different meanings between their experiences of leadership involvement and identities. Literature that interrogates identity within organizations, as well as literature foregrounding leadership identity and models of disability, helped frame this study.

\subsection{Identity Theory}

Identity theory holds we live in structured societies and interact in organized and patterned relationships as individuals and in groups (Hogg, Terry, \& White, 1995; Stryker \& Burke, 2000). We assume roles in society suffused with variant meanings and expectations, particularly among others with whom we are in close relationship. These meanings and expectations establish structured behavior norms (Stets \& Burke, 2000; Stryker \& Burke, 2000). As such, Stryker and Burke (2000) argued, "identities are internalized role expectations" (p. 286) that can be better understood as "cognitive schemas-internally stored information and meanings serving as frameworks for interpreting experience" (p. 286). Further, identity theory seeks to make meaning of roles we occupy and behaviors we perform while interacting with others in similar and different roles (Burke \& Reitzes, 1981). Role behaviors are typified through identity negotiation as we associate self-meanings and expectations to roles and their connection to meanings associated with other social roles (Stets \& Burke, 2000). Additionally, according to Stets and Burke (2000), meanings and expectations we develop toward our idea of 'self' are varied and based on specific roles we are required to activate in particular social contexts and situations. Once an identity activated, individuals engage the cognitive process of verifying that identity in accordance with expectant behaviors associated a particular 
identity standard, or meanings and norms associated with the role (Stets \& Burke, 2000). These meanings affect how we enact commitment toward identities we maintain (Stryker \& Burke, 2000; Stets \& Burke, 2000).

\subsection{Social Identity Theory}

Comparable to identity theory, social identity theory posits identity as bounded by structured society and intergroup relations (Ethier \& Deaux, 1994; Abrams \& Hogg, 1998; Tajfel, 1979). According to Stets and Burke (2000), "...how people come to see themselves as members of one group/category (the in-group) in comparison with another (the out-group)..." (p. 226) is central to social identity development. Social identity is "that part of an individual's self-concept which derives from his knowledge of his membership of a group (or groups) together with the value and the emotional significance attached to the membership" (Tajfel, 1978, p. 63, cited in Van Knippenberg, 2000). In social identity theory, identity saliency entails the extent to which individuals view themselves as an exemplar of the social groups in which they claim membership (Stets \& Burke, 2000; Hogg \& Hardie, 1992). Hogg, Terry, and White (1995) claim in order to achieve social identity salience, we undergo an identity activation process of "depersonalization, or seeing the self as an embodiment of the in-group prototype" (p. 231). Ethier and Deaux (1994) noted when we use group labels to describe each other, we are more apt to involve ourselves in a group's culture, deepening our affinity toward and acceptance of attitudes and behaviors demonstrated by members of our in-group categories.

\subsection{Organizational Identity}

Organizational identity employs tenets of social identity theory to investigate leaders' efforts to not only establish a broad institutional image for their company but also to understand how individuals perceive their own identity within the context of the organization (Albert, Ashforth, \& Dutton, 2000; Ashforth \& Mael, 1989; DeRue \& Ashford, 2010; Hogg \& Terry, 2000; Van Knippenberg, 2000). Organizational identity entails exploring how individuals make meaning of the interactions with others and how such interactions are influenced by broader organizational structures. While building and sustaining the identity and image of a school, principals serve as the public face of the organization (Møller, 2012). Principals are responsible for managing their school's identity, an identity contingent upon public perception influenced by various factors.

\subsection{Professional Identity}

Since earlier seminal research explored by Becker and Carper (1956), professional identity has been studied widely to understand how individuals internalize their vocational identity (Seemiller \& Priest, 2015). Professional identity entails a process of constructing an identity with respects to the ways principals view their work performance and how other affirm their effectiveness as job-embedded abilities (Crow, Day, \& Møller 2017; Scribner \& Crow, 2012). Moreover, principals appraise the vibrancy of their professional identity based on the extent to which they build trusting relationships among various constituents (Crow, Day, \& Møller 2017; Scribner \& Crow, 2012).

\subsection{Disability Perspectives}

Disability may be understood according to belief frameworks, or models. These models, which detail assumptive historical, philosophical, and political views about disability, are used to explicate how and why societies perceive disability and interact with individuals with disabilities in (de)humanizing ways (Michalko, 2002; Shakespeare, 2006; Smart, 2009).

\subsubsection{Medical Model of Disability}

Shakespeare (2006) and Smith and Erevelles (2004) contended ideologies and attitudes grounded in the medical model of disability position disability as a disorder in need of treatment. Proponents of this perspective consider disability a matter of biological dissimilarity, differences between typical and atypical individuals (Smart, 2009). Clapton and Fitzgerald (1997) suggested views pedestrian within this model promote individuals with disabilities have an affliction that requires them to seek myriad forms of medical (or otherwise) intervention. Further, individuals with disabilities are viewed as patients whose disability causes persistent suffrage, especially given the profundity of their physical, mental, or emotional condition (Michalko, 2002; Smith \& Erevelles, 2004). Longmore (2003) argued through various rehabilitative and other related services individuals with disabilities are considered capable of improving their abnormality, thus gaining increased access to more a normalized state of personhood.

\subsubsection{Social Model of Disability}

Antithetical to discourses in the medical model that regard disability an aberration of the natural body (Michalko, 2002), adherents of the social model believe in the importance of advocating conceptual and lived 
understanding of variance between human impairment and disability (Shakespeare, 2006). Shakespeare (2006) argued, "[t]he former is individual and private, the latter is structural and public" (p. 198). Michalko (2002) noted impairment exists within any person given the person's specific life and circumstantial experiences. Proponents of the social model claim research on disability should be driven by meanings and experiences of people with disabilities (Longmore, 2003).

\section{METHODOLOGY OF RESEARCH}

In this study phenomenography was employed. This approach attempts to capture variation in human sensemaking at the conceptual and experiential level and is similar yet distinct from other qualitative approaches (Åkerlind, 2012; Entwistle, 1997; Harris, 2011; Marton, 1981, 1986; Marton \& Booth, 1997; Richardson, 1999; Svensson, 1997). Phenomenography is used to dislodge how persons "describe relations between [themselves](sic) and various aspects of the world around them, regardless of whether those relationships are manifested in the forms of immediate experience, conceptual thought, or physical behavior" (Marton, 1986, cited in Richardson, 1999, p. 60).

\subsection{Participant Selection}

Retired principals (no more than 10 years) with regular and special education certification who worked in public PreK-12 settings were considered for this study. Participants were identified via purposeful sampling, specifically snowball sampling (Biernacki \& Waldorf, 1981; Creswell, 2013; Noy, 2008). Five individuals (Garrick, Andrea, Vincent, Ramona, and Frances) with experience leading special education programs were chosen.

\subsection{Data Generation}

Yates, Partridge, and Bruce (2012) suggested the "phenomenographic interview is semi-structured in nature" (p. 102). Rather than devising full-length questions, participants responded to open-ended prompts. Two interviews were performed with each participant. Interviews varied in length, with first-round interviews typically lasting longer than second round interviews. Participants were asked about their: (1) personal backgrounds, (2) educational and professional training, (3) instructional and leadership experiences, (4) perceptions of disability, and (5) levels of involvement (work) performed with students with disabilities. Second-round interviews were used to probe ambiguously answered questions from the first interview and to gather missed information. Field notes, entries from reflective journaling, and first-level analysis of round-one transcripts were used to guide the development of round-two interview questions.

\subsection{Data Analysis}

Analytical approaches common to phenomenography guided this study (see Åkerlind, 2012; Bowden, 2000; Dahlgren \& Fallsberg, 1991; Green \& Bowden, 2009; Marton, 1981; Marton, 1988; Marton \& Booth, 1997). Phenomenographic analysis involves an iterative process grounded in sustained engagement with interview data (Bowden 2000; Dahlgren and Fallsberg, 1991; Green \& Bowden, 2009; Marton \& Booth, 1997). Data analysis was based on an approach delineated by Dahlgren and Fallsberg (1991) for generating categories of description. Their analytical approach involves seven steps comprised of familiarization, condensation, comparison, grouping, articulation, labeling, and contrasting (Dahlgren \& Fallsberg, 1991).

\subsubsection{Familiarization}

Interviews were transcribed and read start and finish to augment familiarity with interview data. Comments were written in transcription margins to summarize the tone of interview sessions. Minimal time passed between the re-reading of transcriptions and re-listening to recordings to achieve a firmer understanding of context and preliminary interpretations and meanings referenced in participants' reflections of their experiences.

\subsubsection{Condensation}

When condensing interview data, longer key statements were used to create shorter ones. Dahlgren and Fallsberg (1991) suggested extended key statements about the phenomenon should be shortened (condensed) and the meaning of original dialogue preserved. Deep familiarization of interview was required. As I condensed statements on different ways participants experienced leadership involvement in special education, disability, and identity, an Excel spreadsheet file(s) was created to transfer participants' extended and condensed statements onto. Prior notes were used to write summaries of transferred statements. 


\subsubsection{Comparison}

In this step condensed statements were questioned critically to situate commonality between them. These statements and situational narratives reflected in participants' dialogue, rereading offered particularized ways of seeing and understanding participants' expressed conceptions and understanding of leadership involvement and identity. Moreover, identification of similar statements offered tentative subsets of dialogue across interviews (Dahlgren \& Fallsberg, 1991) and aided the reorganization of color-coded statements from the Excel spreadsheet file(s) developed in the prior analytical step.

\subsubsection{Grouping}

This step entailed taking compared statements close in meaning (similarly varied), and grouping them into pools of meanings (Marton, 1981). Statements placed together temporally in the comparison step came under additional scrutiny and were moved as necessary to align within newly formed pools of meaning. Statements were then placed in various pools (groups) to show complexity of participants' conceptions and understanding of their experiences (Marton, 1981) before moving forward with the next step. Statements or conceptions less complex in experience and meaning (those more commonly shared across participants) gave way to statements or conceptions more complex (those less commonly shared across participants).

\subsubsection{Articulation}

This process involved writing (articulating) in my reflexive journal how descriptions of statements within each grouped pool of meaning were similar. Here, a constant review of research comments previously scribed in transcription margins, notes composed in my reflective journal, and similar and contrasting patterns of participants' descriptions (statements) of experiences across grouped pools of meaning was required. Revised descriptions were written based upon regrouped statements, especially when they resulted in the merging or creation of new pools of meaning.

\subsubsection{Labelling}

Labelling requires researchers to make "a suitable linguistic expression" (Dahlgren \& Fallsberg, 1991, p. 152 ) to signify the essence of descriptions (meanings of conceptions) for each grouped pool of meaning. Marton and Booth (1997) contended categories of description should: (a) stand as individual categories in clear relation to the aspect of the world under investigation so that each category tells us something distinct about a particular way of experiencing an aspect of the world; (b) stand in a logical relationship with one another; and (c) represent few categories as possible should capture the critical variation in the data. In this step, labels provided final classifications for the pools of meaning previously comprised.

\subsubsection{Contrasting}

When contrasting, labeled categories of descriptions were (re)examined and finalized differences (variation) in meaning across interview data were established. Sets of contrasting labels (categories of descriptions) were then used to develop the outcome space-an illustration of how "the complex of different experiences which together comprise the phenomenon and represents the phenomenon in the same way as categories of description represent conceptions" (Yates, Partridge, \& Bruce, 2012, p. 106). Final categories of description and the outcome space they create depicts variation on a collective level (across all interviews).

\section{FINDINGS}

The retired principals' accounts of being, becoming, and remaining involved with special education and/or disability conceptually differentiated involvement as the experience of active presence, critical reflection, advocacy, and resistance. Participants' accounts of involvement were influenced by personal beliefs and attitudes about students with disabilities (Ball \& Green, 2014; Carter \& Hughes, 2006; Crockett et al., 2007; Praisner, 2003; Zaretsky et al., 2008).

\subsection{Outcome Space}

The outcome space (Figure 1) illustrates threads of categories of description and participants' awareness of leadership involvement and identity. Findings representing leadership involvement are presented vertically and those representing leadership identity are presented horizontally. Categories of description of leadership involvement and leadership identity are interwoven, interconnecting with each other to delineate variation in participants' involvement experiences in special education and leadership identity. Depths in participants' understanding of involvement and leadership identity were bounded to their sense of awareness (Marton \& Booth, 1997). Rands and Gansemer-Topf (2016) suggested awareness in phenomenographic research 
attempts "to capture the object of understanding or experience (the phenomenon), and this cannot be separated from the way it is experienced or understood" (p. 8). Participants' perspectives of awareness included professional response, risk-taking, and social transformation.

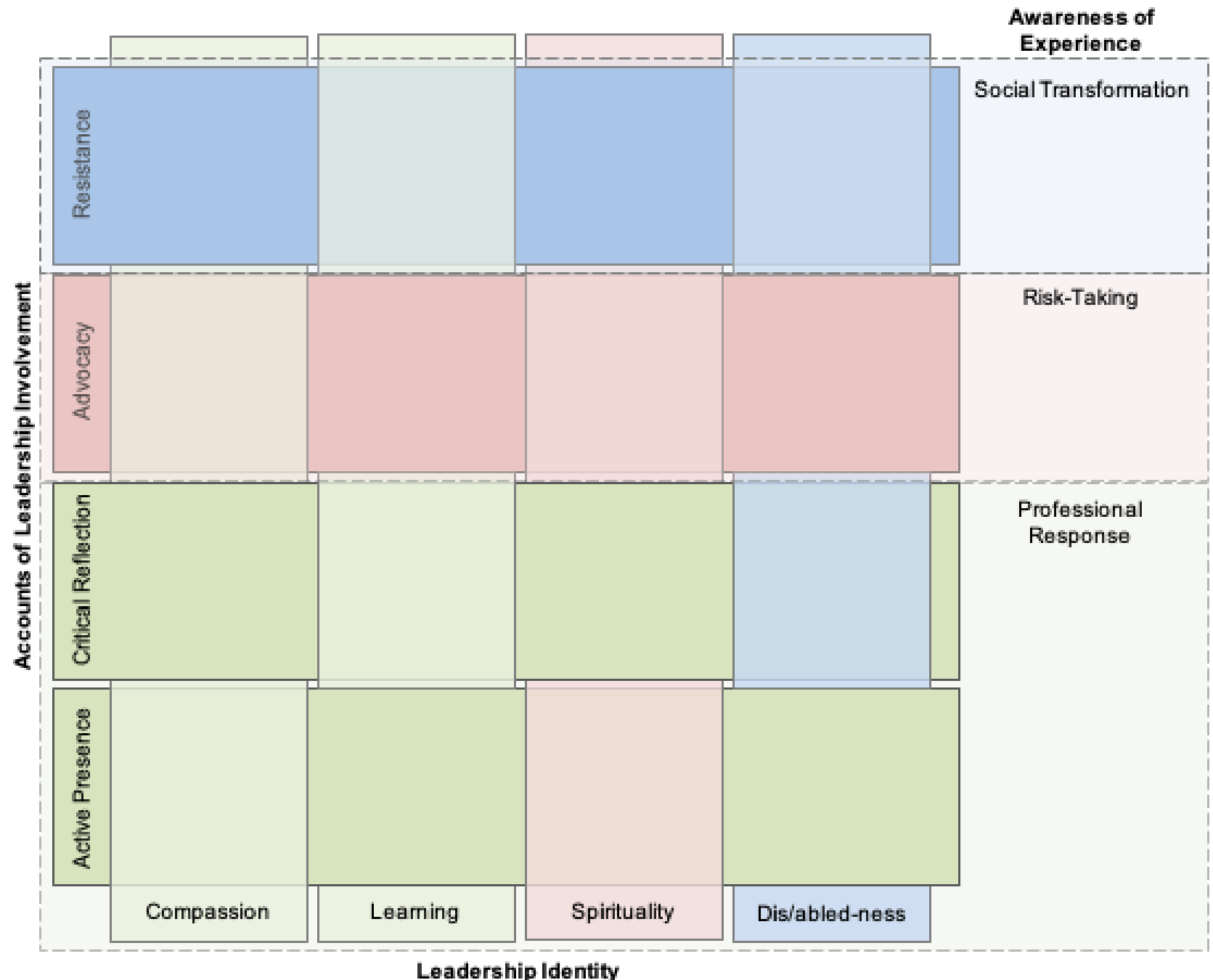

Figure 1. Outcome Space.

Arranged this way, variations in meaning between/across participants' accounts are relationally situated in connection to participants' understanding of the phenomenon and are called themes of awareness. They positioned at the right margin of the outcome space and undergird categories of description. These themes of awareness scaffold four primary categories of leadership involvement and four categories of leadership identity. Dotted lines around the themes of awareness signify structural and conceptual interplay between/across the categories of description and awareness of experience. Levels of awareness strengthen dimensionalities of variation throughout the outcome space.

\subsection{Variation Between/Across Categories of Description}

According to Marton and Booth (1997), categories of description should: (a) stand as individual categories in clear relation to the aspect of the world under investigation so that each category tells us something distinct about a particular way of experiencing an aspect of the world; (b) stand in a logical relationship with one another; and (c) be represented by few categories as possible and capture the critical variation in the data. In addition, categories of description are not meant to be symbolic of or reducible to how any single participant made meaning of his or her leadership involvement experience and identity but rather exemplify a collective of meanings shared and contrasted between participants (Åkerlind, 2012; Bowden \& Green, 2009). Demonstrating how participants' variation in meaning exists between/across involvement and identity categories of description, the following section draws from distinct analytical examples provided in this study. It is important to note while these examples stand in logical relationship, some can be represented at the 
Proceedings of SOCIOINT 2020-7th International Conference on Education and Education of Social Sciences, 15-17 June 2020

intersection of other descriptive categories

\subsubsection{Active Presence Between/Across Identity Constructions}

Active presence as involvement typifies the retired principals' participation in special education meetings, classrooms, and interactions among students with disabilities. Immediate examples illustrate how involvement as active presence intersects with identity constructed through compassion. At this intersection every participant offered an account(s) that directly invoked or intimated how they felt a sense of compassion for students and families as they attended to students' and parents' interests, whether observed within the context of special education meetings or other school-wide activities. Additionally, some participants shared ways they actively sought experiences that allowed them to learn more about special education and students with disabilities from others, illustrating variation at the intersection of active presence and identity constructed through learning. This was captured by Andrea's repeated declaration, "how [can] we support that child?" By way of involving herself in special education meetings and classrooms, Andrea engaged in problem solving to activate her identity as a learner.

Through experiences of active presence, Ramona activated an identity of dis/abled-ness. As a parent of a child with a disability, Ramona became acutely aware of issues facing special education students, which included constant need to hire personnel and repair (poor) facility conditions. She discussed how she helped clean ESE classrooms when her school's janitorial staff was understaffed, commenting, "you have to model what you want others to do. I couldn't just sit there in my suit and do nothing." As participants reflected upon experiences of active presence in special education and with students with disabilities, they also activated other identity role constructions.

\subsubsection{Critical Reflection Between/Across Identity Constructions}

Critical reflection as involvement typifies participants' engagement in ongoing reflection to reexamine their leadership practice and school-wide policies for special education and with students with disabilities. Participants' experiences of involvement as critical reflection intersected with different identity constructions. For example, critical reflection and identity constructed through compassion is exemplified by an account offered by Frances. Frances shared she felt she "did not involve parents in the happy things at school," exhibiting capacity to reflect on how her actions may have shown a lack of compassion toward parents of children with disabilities.

Alternatively, some participants described how they engaged in critical reflection while constructing a sense of identity through learning. For instance, Andrea recounted how she learned from and adjusted her leadership practice when reprimanded by district for over-disciplining a student with a disability. This experience expanded her learner identity construction to include another identity based on compassion as her leadership practice thereafter embraced a more problem-solving approach that first considered students with disabilities needs rather than labeling them "good" or "bad". Similarly, Vincent referenced "problemsolving" (critical reflection) to demonstrate how he personally reflected-along with his administrative and instructional staff-how best to provide inclusive educational services for students with disabilities, which necessitated the activation of a learner identity.

The intersection of critical reflection as involvement and spirituality as an identity was present among participants. Recalling involvement experiences that summoned critical reflection, Ramona discussed how she drew from her sense of spirituality. Ramona discussed she invoked God as she struggled to make decisions that may have adversely impacted students with disabilities. For example, Ramona reflected pensively about a student with an emotional disability she agreed to send to a residential program, absolving in a prayer-like manner "oh God, maybe I should have just tried a little bit harder with him."

\subsubsection{Advocacy Between/Across Identity Constructions}

Advocacy as involvement typifies how participants enacted institutional practices to address issues pertaining to social equity and fairness. Involvement experiences of advocacy interacted with various identity constructions. The following examples highlight the intersectionality of involvement as advocacy and identity constructed through compassion. For instance, Garrick discussed how he advocated for students with more severe disabilities to be included in the school culture by creating a student-run coffee shop in attempt to make them feel more valued as members of the school. Similarly. Frances used her influence to disrupt social and infrastructure barriers that precluded students' inclusion in general education and ability to utilize the school's resources. She was concerned about creating a school environment where students with disabilities felt part of a larger community. 
Moreover, Garrick, referred to the exclusion or segregation of students with disabilities as "not right". He tended take moral stances based on his humanist (spiritual) beliefs. Here, we see involvement experienced though advocacy as an outgrowth of critical reflection, which in turn intersected with his sense of identity constructed through spirituality. Further, he instituted school-wide changes such as integrated lunches and encouraged general education students to build relationships with students with more significant disabilities to facilitate a culture of inclusion and respect among all students.

Lastly, Garrick and Vincent, when helping students and parents navigate special education services and procedures, often shared challenges they faced throughout their personal schooling experiences and career as a result of their own disability. As a way of advocating for students with disabilities, Garrick commented he shared his experiences with students because "I didn't want children to feel how I felt". Vincent wanted parents and students to know he "understood what it was like" to struggle academically due to his inability to read. Similarly, Ramona often shared her experiences as a mother to a child with a disability to help build relationships with parents and students. These examples illustrate the intersections of involvement experienced as advocacy and identities constructed through compassion and dis/abled-ness.

\subsubsection{Resistance Between/Across Identity Constructions}

Transitioning beyond advocating on behalf of students with disabilities, resistance as involvement represents ways some participants engaged in systemic, institutionally driven efforts to spurn practices and beliefs that marginalized students with disabilities. Involvement experiences as resistance interacted with various identity constructions. Frances demonstrated involvement as resistance when she moved special education classrooms into the general education areas of her school. As teachers (general and special) expressed frustration with these changes, requesting their classrooms and students not to be encroached upon by "others", Frances followed through on her decision despite teachers' reactions. Further, she discussed how she felt children with disabilities should have access to the school campus and be treated with respect. Frances' reflective accounts provided evince the intersection of resistance and compassion for children with disabilities.

Drawing from another example, Ramona's involvement oftentimes resided on "you had to fight" district to get students with disabilities what they needed. Demonstrating the mettle of her willingness to resist what she considered social and economic injustices perpetuated by district officials, Ramona contacted the local news when district officials refused to fix facilities at her school, placing her job and reputation in jeopardy. Reflecting upon her experience of resistance, she frequently referenced to God and her spirituality as a source of strength. Furthermore, after having a child with a disability, Ramona recounted how she often viewed herself as the "gatekeeper" of students with disabilities rights, which also endowed her to wage battles of resistance. Given these examples, Ramona's frequent invocation of God and positionality as "gatekeeper" signified intersections of resistance and identities constructed through spirituality and dis/abledness.

\section{DISCUSSION}

Drawing literature and findings, subsequent discussion highlights the intersection of personal experience with disability and confidence and how these notions conjoined to influence participants' involvement in special education programs and students with disabilities.

\subsection{Catalyst for Involvement}

According to Christenson et al. (2013), principals' ability (or willingness) to commit time to be adequately trained in special education was integral to their efforts to remain conversant with knowledge to lead in special education, which included gaining knowledge of curriculum modification, discipline practices, testing accommodations, and laws affecting special education programs and students. For instance, Ramona described efforts to augment her knowledge by attending district trainings, resulting in her earning professional certification in this field. Moreover, Andrea actively sought input and feedback from "the experts" (i.e., special education teachers, district leaders, etc.) to strengthen her capacity to lead in special education.

Findings also revealed how participants engaged in direct enactments of (un)orthodox practices and skills specific to special education leadership. Garrick discussed attempts made to participate in as many IEP meetings he could, intent on "listening to understand". Andrea conceived of her role as providing support to special education teachers by listening to their concerns, following teachers' lead when called upon to implement student interventions, and securing requested resources. Having established a positive, internalized sense of competence and ability to engage in established special education practices, some participants were enabled to respond in ways that (re)affirmed their beliefs and influenced their ability to 
Proceedings of SOCIOINT 2020- 7th International Conference on Education and Education of Social Sciences,

become more involved with students, teachers, parents, and other stakeholders in special education.

Another marked characteristic of leadership involvement entailed participants' inclination to employ deep self-reflection to mitigate his or her beliefs regarding the personhood of individuals with disabilities. This required principals to actively pursue/possess knowledge about special education and students with disabilities and critically reflect upon how such knowledge (mis)aligned with their beliefs and practices. For example, Garrick discussed perturbation he experienced over his decision to integrate students with profound disabilities into general education lunch periods. His consternation and advocacy were predicated on his beliefs that "there is nothing wrong" with individuals and disabilities and they too are worthy of respect through increased social participation among peers.

\subsection{Personal Experience with Disability}

Findings suggest personal relationships and experiences with individuals with disabilities appeared to influence participants' involvement in special education programs and with students with disabilities (Wakeman et al., 2006; Zaretsky, 2008). Participants who did not or had limited personal experiences with disability tended to rely more on others to guide their leadership in special education and/or disability. For instance, Andrea and Frances had limited personal experiences with disability and tended to rely more on "experts" than other participants. Alternatively, Ramona and Garrick, who both had a child with a disability, seemed more comfortable leading in special education and experienced.

Wakeman et al. (2006) found principals who had prior work experience or personal relationships with individuals with disabilities were more knowledgeable about special education issues and more likely to advocate for students with disabilities. This was evident in findings drawn from this study. For example, Garrick had experience working with individuals with disabilities in the community before entering education. He accredited this prior experience to his involvement and advocacy for students with disabilities. In addition, Garrick's early life experience with having an aunt who was institutionalized helped shape his orientation against the stigmatization and marginalization of persons with disabilities.

Similarly, Zaretsky et al. (2008) suggested principals connected the importance of providing leadership in special education to personal experience. One of Zaretsky et al.'s (2008) participants shared working for and helping students with disabilities was "who I was and who my family was" (p. 166). This was consistent with Ramona's account in the current study. Contrasting her life experiences before and after giving birth to a child with a disability, Ramona recounted that was when "the blinders came off", allowing her to see special education programs and students in a new paradigmatic way. The impact of parenting a child with a disability influenced some participants involvement in special education and disability through forms of advocacy and resistance. Such personal experiences encouraged them to work toward the socially transforming their schools.

\section{CONCLUSION}

Involving themselves in special education and understanding their experiences through different levels of awareness, participants in this study experienced and activated their identities in ways that (re)affirmed their beliefs toward improving the educational experiences and lives of students with disabilities. Furthermore, participants' accounts illustrate variation in the ways they actively sought to (re)construct their identities as their involvement in special education and students with disabilities changed over the course of their careers. This study illuminates the importance of understanding identity as it relates to the principalship and how notions of identity work to influence a principal's involvement in special education programs and students. According to Riehl (2009), "If practice is connected to identity then it matters who administrators are" ( $p$. 191). Through one's role as a school principal, involvement in special education and/or disability, coupled with personal experience with dis/abled-ness, principals can lead toward more humanistic and inclusive schools.

\subsection{Implications for Leadership Preparation}

Researchers and educational leadership development programs may consider findings significant. This study can encourage discussion with regards to the ways individuals are recruited and prepared to lead schools, focusing selection and preparation conversations around how aspiring leaders understand role expectations associated with leadership in special education. Leadership preparation programs can help future leaders better understand "social meanings associated with [identity] categories" (Deaux, 1993, p. 4) that may limit how they see themselves in relation to certain groups of students they will lead. The provocation of different conversations and ways of helping future leaders to acknowledge the experiences of groups of students who would otherwise go unnoticed. In addition, research that interrogates closer the 
extent which principals are socialized for leadership not only in educational leadership programs but more broadly within varied organizational contexts (at district-level and school-based settings) can help establish a better understanding of how they come to affirm their sense of organizational identity. Schools are places where many organizational structures exist, and principals play an integral role managing discourses and interactions between organizational members. Leadership preparation programs can help unpack socializing processes principals undergo in how they perceive themselves professionals.

\subsection{Implications for Future Research}

Research that interrogates influences of principals' involvement in special education, unpacks their expanded sense of awareness illuminating the (in)attention they provide to students with disabilities, and what they desire to achieve from their involvement in this area of leadership is warranted. When having to deal with issues specific to special education and students with disabilities, principals may be required to advocate for and resist social structures that obstruct or suppress the humanity, respect, and inclusion of students with disabilities. Increased understanding of why and how principals' identity is conceptualized and legitimated to resolve internal and external conflicts when leading in special education can be useful. Moreover, future research should seek to address the unique positionality of principals who are parents of a child(ren) with a disability/ies. The role principals who have a child a with disability may play when enacting a social justice orientation can potentially offer revised or a new of way of envisioning leadership research and preparation, particularly for researchers interested in understanding leadership in special education.

Additionally, a phenomenographic approach to analyzing data in educational leadership can provide a different methodological tool for unearthing robust understanding into varied insights and meanings specific to how leadership phenomena are experienced, especially how participants describe and experience phenomena through their attendant state of awareness. For the purposes of this study, this approach was grounded in variation in meanings connected to participants' experiences of involvement in special education and/or disability and their leadership identity. Future research may utilize this method to examine variation in meaning across a sample of participants that include district-level leaders, other site-based based leaders such as assistant principals and teacher leaders, parent advocates, student leaders, and community leaders.

\section{REFERENCE LIST}

Abrams, D., \& Hogg, M. A. (1998). Prospects for research in group processes and intergroup relations. Group Processes \& Intergroup Relations, 1(1), 7-20.

Åkerlind, G. S. (2012). Variation and commonality in phenomenographic research methods. Higher Education Research \& Development, 31(1), 115-127.

Albert, S., Ashforth, B. E., \& Dutton, J. E. (2000). Organizational identity and identification: Charting new waters and building new bridges. Academy of Management Review, 25(1), 13-17.

Ashforth, B. E., \& Mael, F. (1989). Social identity theory and the organization. Academy of Management Review, 14(1), 20-39.

Ball, K., \& Green, R. L. (2014). An investigation of the attitudes of school leaders toward the inclusion of students with disabilities in the general education setting. National Forum of Applied Educational Research Journal, 27(1/2), 57-76.

Bakken, J. P., O’Brian, M., \& Sheldon, D. L. (2006). Changing roles and responsibilities of special education administrators: Impact on multicultural learners. Educational Considerations, 34(1), 3-8.

Bays, D. A., \& Crockett, J. B. (2007). Investigating instructional leadership for special education. Exceptionality, 15(3), 143-161.

Becker, H. S. \& Carper, J. W. (1956). The development of identification with an occupation. American Journal of Sociology, 61(4). 289-298.

Biernacki, P., \& Waldorf, D. (1981). Snowball sampling: Problems and techniques of chain referral sampling. Sociological Methods \& Research, 10(2), 141-163.

Bineham, S. C., Shelby, L., Pazey, B. L., \& Yates, J. R. (2014). Response to intervention: 
Perspectives of general and special education professionals. Journal of School Leadership, 24(2), 230-252.

Black, W. R., \& Simon, M. D. (2014). Leadership for all students: Planning for more inclusive school practices. International Journal of Educational Leadership Preparation, 9(2), 153-172.

Bowden, J. A. (2000). The nature of phenomenographic research. In J. Bowden and E. Walsh. (Eds.). Phenomenography (pp. 1-18.) Melbourne, Australia: RMIT University Press.

Bruce, C. (1994, November). Reflections on the Experience of the Phenomenographic Interview. Paper presented at Phenomenography: Philosophy and Practice Conference, Queensland University of Technology, Brisbane, Australia.

Burke, P. J., \& Reitzes, D. C. (1981). The link between identity and role performance. Social Psychology Quarterly, 44(2), 83-92.

Burrello, L. C., Sailor, W., \& Kleinhammer-Tramill, J. (2013). Unifying educational systems: Leadership and policy perspectives. New York: Routledge.

Carter, E. W., \& Hughes, C. (2006). Including high school students with severe disabilities in general education classes: Perspectives of general and special educators, paraprofessionals, and administrators. Research and Practice for Persons with Severe Disabilities, 31(2), 174-185.

Christensen, J., Roberston, J. S., Williamson, R., \& Hunter, W. C. (2013). Preparing educational leaders for special education success: Principals' perspective. The Researcher, 25(1), 94-107.

Clapton, J., \& Fitzgerald, J. (1997). The history of disability: A history of' otherness'. New Renaissance Magazine, 7(1), 1-3.

Creswell, J. (2013). Qualitative inquiry and research design: Choosing among five approaches. $3^{\text {rd }}$ ed. Thousand Oaks, California: Sage.

Crockett, J. B., Myers, S. T., Griffin, A., \& Hollandsworth, B. (2007). The unintended side effects of inclusion for students with learning disabilities: The perspectives of school administrators. Journal of Learning Disabilities, 14(3), 155-166.

Crow, G., Day, C., \& Møller, J. (2017). Framing research on school principals' identities. International Journal of Leadership in Education, 20(3), 265-277.

Dahlgren, L. O., \& Fallsberg, M. (1991). Phenomenography as a qualitative approach in social pharmacy research. Journal of Social and Administrative Pharmacy, 8(4), 150-156.

Deaux, K. (1993). Reconstructing social identity. Personality and Social Psychology Bulletin, 19(1), 4-12.

DeRue, D. S., \& Ashford, S. J. (2010). Who will lead and who will follow? A social process of leadership identity construction in organizations. Academy of Management Review, 35(4), 627-647.

Entwistle, N. (1997). Introduction: Phenomenography in higher education. Higher Education Research \& Development, 16(2), 127-134.

Ethier, K. A., \& Deaux, K. (1994). Negotiating social identity when contexts change: Maintaining identification and responding to threat. Journal of Personality and Social Psychology, 67(2), 243.

Frattura, E., \& Capper, C. A. (2006). Segregated programs versus integrated comprehensive service delivery for all learners: Assessing the differences. Remedial and Special Education, 27(6), 355-364.

Frick, W. C., Faircloth, S. C., \& Little, K. S. (2013). Responding to the collective and individual "best interests of students" Revisiting the tension between administrative practice and ethical imperatives in special education leadership. Educational Administration Quarterly, 49(2), 207-242.

Frost, L. A., \& Kersten, T. (2011). The role of the elementary principal in the instructional leadership of special education. International Journal of Educational Leadership Preparation, 6(2), 1 21.

Fuchs, D., Fuchs, L. S., \& Stecker, P. M. (2010). The "blurring" of special education in a new continuum of general education placements and services. Exceptional Children, 76(3), 301-323.

Green, P., \& Bowden, J. (2009). Principles of developmental phenomenography. Malaysian Journal of 
Qualitative Research, 2(2), 55-74.

Harris, L. R. (2011). Phenomenographic perspectives on the structure of conceptions: The origins, purposes, strengths, and limitations of the what/how and referential/structural frameworks. Educational Research Review, 6(2), 109-124.

Hogg, M. A., \& Hardie, E. A. (1992). Prototypicality, conformity and depersonalized attraction: A selfcategorization analysis of group cohesiveness. British Journal of Social Psychology, 31(1), 41-56.

Hogg, M. A., \& Terry, D. J. (2000). Social identity and self-categorization processes in organizational contexts. Academy of Management Review, 25(1), 121-140.

Hogg, M. A., Terry, D. J., \& White, K. M. (1995). A tale of two theories: A critical comparison of identity theory with social identity theory. Social Psychology Quarterly, 58(4), 255-269.

Lashley, C., \& Boscardin, M. L. (2003). Special education administration at a crossroads. Journal of Special Education Leadership, 16(2), 63-75.

Lasky, B., \& Karge, B. (2006). Meeting the needs of students with disabilities: Experience and confidence of principals. NASSP Bulletin, 90(1), 19-36.

Longmore, P. (2003). Why I burned my book and other essays on disability. Philadelphia, PA: Temple University Press.

Marton, F. (1981). Phenomenography: Describing conceptions of the world around us. Instructional Science, 10(2), 177-200.

Marton, F. (1986). Phenomenography: A research approach to investigating different understandings of reality. Journal of Thought, 21(3), 28-49.

Marton, F. (1988). Phenomenography: A research approach to investigating different understandings of reality. In R. Sherman \& R. Webb (Eds.). Qualitative research in education: Focus and methods (pp. 143-161). Philadelphia, PA: The Falmer Press.

Marton, F., \& Booth, S. (1997). Learning and awareness. Mahwah, NJ: Erlbaum.

Michalko, R. (2002). The difference that disability makes. Philadelphia, PA: Temple University Press.

Møller, J. (2012). The construction of a public face as a school principal. International Journal of Educational Management, 26(5), 452-460.

Noy, C. (2008). Sampling knowledge: The hermeneutics of snowball sampling in qualitative research. International Journal of Social Research Methodology, 11(4), 327-344.

Palladino, J. M. 2013. The tears of tiers: A leadership response to teachers' challenges with RTI. In K. K. Hewitt (Ed). Postcards from the Schoolhouse: Practitioner scholars examine contemporary issues in instructional leadership (pp. 47-67). Michigan: NCPEA Publications.

Provost, J., Boscardin, M. L., \& Wells, C. (2010). Perceptions of principal leadership behaviors in Massachusetts in the era of education reform. Journal of School Leadership, 20(5), 532-560.

Rands, M., \& Gansemer-Topf, A. M. (2016). Phenomenography: A methodological approach for assessment in student affairs. Journal of Student Affairs Inquiry, 1(2), 1-22.

Rhodes, C., \& Greenway, C. (2010). Dramatis personae: Enactment and performance in primary school headship. Management in Education, 24(4), 149-153.

Richardson, J. T. (1999). The concepts and methods of phenomenographic research. Review of Educational Research, 69(1), 53-82.

Richter, M. M., Lewis, T. J., \& Hagar, J. (2011). The relationship between principal leadership skills and school-wide positive behavior support: An exploratory study. Journal of Positive Behavior Interventions, 14(2), 69-77.

Riehl, C. J. (2009). The principal's role in creating inclusive schools for diverse students: A review of normative, empirical, and critical literature on the practice of educational administration. Journal of Education, 189(1-2), 183-197.

Sansosti, F. J., Noltemeyer, A., \& Goss, S. (2010). Principals' perceptions of the importance and availability 
of response to intervention practices within high school settings. School Psychology Review, 39(2), 286-295.

Scribner, S. P., \& Crow, G. M. (2012). Employing professional identities: Case study of a high school principal in a reform setting. Leadership and Policy in Schools, 11(3), 243-274.

Seemiller, C., \& Priest, K. L. (2015). The hidden "who" in leadership education: Conceptualizing leadership educator professional identity development. Journal of Leadership Education, 14(3).

Shakespeare, T. (2006). The social model of disability. In L. Davis. (Eds.). The disability studies reader. (pp. 197-204). New York: Routledge.

Skiba, R. J., Simmons, A. B., Ritter, S., Gibb, A. C., Rausch, M. K., Cuadrado, J., \& Chung, C. G. (2008). Achieving equity in special education: History, status, and current challenges. Exceptional Children, 74(3), 264-288

Smart, J. F. (2009). The power of models of disability. Journal of Rehabilitation, 75(2), 3-11.

Smith, R. M., \& Erevelles, N. (2004). Towards an enabling education: The difference that disability makes. Educational Researcher, 33(8), 31-36.

Stets, J. E., \& Burke, P. J. (2000). Identity theory and social identity theory. Social Psychology Quarterly, 63(4), 224-237.

Stryker, S., \& Burke, P. J. (2000). The past, present, and future of an identity theory. Social Psychology Quarterly, 63(4), 284-297.

Svensson, L. (1997). Theoretical foundations of phenomenography. Higher Education Research \& Development, 16(2), 159-171.

Tajfel, H. (1979). Individuals and groups in social psychology. British Journal of Social and Clinical Psychology, 18(2), 183-190.

Van Acker, R., Boreson, L., Gable, R. A., \& Potterton, T. (2005). Are we on the right course? lessons learned about current FBA/BIP practices in schools. Journal of Behavioral Education, 14(1), 35-56.

Van Knippenberg, D. (2000). Work motivation and performance: A social identity perspective. Applied psychology, 49(3), 357-371.

Wakeman, S.Y., Browder, D. M., Flowers, C., \& Delzell-Ahlgrim, L. (2006). Principals' knowledge of fundamental and current issues in special education. National Association of Secondary School Principals Bulletin, 90(2), 153-174.

Wiener, R. M., \& Soodak, L. C. (2008). Special education administrators' perspectives on response to intervention. Journal of Special Education Leadership, 21(1), 39-45.

Yates, C., Partridge, H., \& Bruce, C. (2012). Exploring information experiences through phenomenography. Library and Information Research, 36(112), 96-119.

Zaretsky, L. (2005). Parent advocates' and principals' perceptions of professional knowledge and identity in special education. Journal of Special Education Leadership, 18(2), 30-40. 